\title{
Regulation of microbial enzymatic degradation of organic matter in deep-sea sediments
}

\author{
Antje Boetius, Karin Lochte \\ Alfred-Wegener-Institut für Polar- und Meeresforschung, PO Box 120161, D-27515 Bremerhaven, Germany
}

\begin{abstract}
The enzymatic response of a natural deep-sea microbial community to input of organic matter was investigated by substrate enrichment experiments. Sediments from the BIOTRANS area at $47^{\circ} \mathrm{N} 20^{\circ} \mathrm{W}$ in the NE Atlantic ( $4500 \mathrm{~m}$ depth) were supplied with particulate and dissolved organic matter from sterilized net plankton and incubated under in situ pressure and temperature. Changes in the potential hydrolytic activities of the extracellular enzymes $\alpha$ - and $\beta$-glucosidase, chitobiase, lipase and aminopeptidase were observed over a $15 \mathrm{~d}$ incubation period. Direct microscopic counts and phospholipid concentrations were used as measures of microbial biomass. Induction of enzyme production proportional to the supply of organic matter was found for enzymes degrading structural polysaccharides ( $\beta$-glucosidase, chitobiase), while aminopeptidase activity was inhibited and no clear effect was found for enzymes degrading storage compounds ( $\alpha$-glucosidase and lipase). Particulate organic matter induced higher enzyme production than equivalent amounts of dissolved organic matter. Only a slight increase in microbial biomass was observed until the end of the experiment after $15 \mathrm{~d}$ indicating that changes in enzyme activity were not due to bacterial growth. The observations give evidence that the production of enzymes in natural mixed microbial communities is directly regulated by the supply of appropriate food.
\end{abstract}

KEY WORDS: Bacteria - Deep-sea - Sediments - Extracellular enzymes - Organic matter

\section{INTRODUCTION}

Particulate organic material (POM) that has settled from the euphotic zone serves as the main food source of benthic organisms. Depending on the origin, composition and size of the particles, their sinking velocity can vary greatly (Alldredge \& Silver 1988). While sinking through the water column, the particles are altered by grazing, microbial degradation and chemical processes (Karl et al. 1988). These processes affect the nutritive value of the particles which generally decreases during prolonged sinking times (Banse 1990). Easily degradable substances such as starch, protein and fat are already removed in the pelagic food web (Smith et al. 1992, Hoppe et al. 1993). The 'leftovers' reaching the deep-sea floor are less-degradable substances such as cellulose, chitin and various proteinaceous structural compounds.

Of all organisms, bacteria are the most adaptable to all kinds of energy resources. Only a few heterotrophs, apart from bacteria and fungi, can hydrolyse structural compounds such as cellulose and chitin (Lee 1980). Bacterial communities contain a broad range of genetic information to build up specific enzymes for the degradation of organic material. This ability, which is exploited for industrial purposes, should also provide advantages for survival under the poor nutritional conditions in the abyssal environment. This was suggested as a potential explanation for the dominance of bacterial biomass in deep-sea sediments, which was found to make up as much as $90 \%$ of total benthic biomass (Rowe et al. 1991, Tietjen 1992, Pfannkuche 1993).

Since bacteria only take up small molecules, they have to cleave polymeric substrates extracellularly. Therefore, the activity of extracellular hydrolytic enzymes is a controlling factor (Billen 1982, Meyer-Reil 1991) for the rate of microbial breakdown of POM and the rate of supply of monomeric and oligomeric molecules to either the bacterial metabolism or the dissolved organic matter (DOM) pool.

The regulation of hydrolytic enzyme production determines the hydrolytic potential of microbial com- 
munities. Most of the extracellular hydrolytic enzymes are regulated by substrate induction, catabolite repression or competition (Priest 1984, Coleman et al. 1987). Investigations with natural mixtures of microbial organisms from freshwater (Chróst \& Overbeck 1990) and marine environments (Köster et al. 1991) showed that the microbial communities reacted to altered substrate availability by significant changes in enzyme production. Hoppe (1991) and Karner \& Herndl (1992) found elevated hydrolytic activity in attached bacteria compared to free-living cells which could be caused either by substrate induction or by different bacterial species associated with particles.

Very little is known about the regulation of hydrolytic enzyme activity in deep-sea sediments, although in this environment bacterial nutrition is almost exclusively based on macromolecular organic matter. Despite the high standing stock of sediment bacteria (Lochte 1991) their growth rates are very low and they are generally supposed to be substrate limited. Input of POM, however, can cause an increase in microbial growth on a time scale of days (Turley \& Lochte 1990) indicating the necessity of a quick enzymatic reaction by sediment bacteria. Such enzymatic reaction to the input of detrital material was observed in pelagic sediments by Meyer-Reil \& Köster (1992). This leads to the question of how microbial hydrolytic activity is regulated by natural substrates in a nutrientlimited environment.

The aim of our experiments was to investigate the relationship between the supply of natural substrates and different hydrolytic enzymes in deep-sea sediments, focusing on the regulatory mechanisms of a natural microbial community. The different enzymes were found to vary in their regulation mechanisms, and dissolved and particulate matter resulted in different quantitative enzymatic responses.

\section{METHODS}

Sediment samples. The experiment was carried out with sediments sampled using a multiple corer (Barnett et al. 1984) during RV 'Meteor' cruise M21/6 in August 1992 in the BIOTRANS area $\left(47^{\circ} \mathrm{N}, 20^{\circ} \mathrm{W}, 4500 \mathrm{~m}\right.$ depth). The sediments are of pelagic origin, consist of fine clay and are well oxygenated in the upper layers. At stations in the NE Atlantic, 3 to $4^{\circ}$ east of the BIOTRANS area, Rutgers van der Loeff (1990) measured oxygen depletion at sediment depths not less than 60 to $100 \mathrm{~cm}$. Previous investigations found highest abundances of bacterial cells and maxima in enzyme activities (Boetius in press) in the top $2 \mathrm{~cm}$. This layer also contains $90 \%$ of the meiofauna (Pfannkuche et al. 1990 ) and is well mixed by bioturbation.
The sediment samples were transferred to a cold room immediately after sampling and all sample handling was carried out at in situ temperature. The 0 to $2 \mathrm{~cm}$ layers from several cores were combined and diluted $1: 1$ with sterile filtered $(0.2 \mu \mathrm{m})$ deep-sea water.

Substrate preparation. The intention of the experiment was to enrich deep-sea sediment with a complex, natural substrate. For this reason dissolved and particulate fractions of homogenized plankton were used. Although such fresh organic material does not normally reach the deep-sea floor via sedimentation, it contains the different components of naturally occurring organic matter and is, therefore, a suitable substrate to study the regulation mechanisms of different hydrolytic enzymes.

Net plankton, mainly consisting of zooplankton, collected with a $100 \mu \mathrm{m}$ hand net was homogenized and autoclaved. The POM fraction was separated from the dissolved phase by centrifugation, washed 3 times with sterile filtered seawater and resuspended to a concentration of $4.5 \mathrm{mg}$ ( $\mathrm{SD} \pm 0.9 \mathrm{mg}, n=5$ ) of particulate organic carbon $\mathrm{ml}^{-1}(\mathrm{C}: \mathrm{N}$ ratio $=5.6)$ as determined by a Carlo-Erba CHN analyzer 1500 according to the procedure of Grasshoff et al. (1983).

The supernatant resulting from homogenizing and autoclaving the plankton mixture was also used as a food supply to test the difference in the microbial response to dissolved and particulate material. The DOM fraction contained $12.1 \mathrm{mg}(\mathrm{SD} \pm 0.13 \mathrm{mg}, \mathrm{n}=9$ ) of organic carbon $\mathrm{ml}^{-1}$ as determined by the high-temperature combustion method (Shimadzu TOC 5000) at $680^{\circ} \mathrm{C}$ with $0.5 \%$ platinum on aluminium oxide as a catalyst.

Experimental design. The sediment slurries were mixed with POM substrate to final concentrations of $15 \mathrm{mM}$ organic $\mathrm{C}$ and $26 \mathrm{mM}$ organic C. DOM substrate was added to final concentrations of 20 and $40 \mathrm{mM}$ organic C. Sediment slurry without additional substrate served as control. All mixtures were divided into $20 \mathrm{ml}$ portions and sealed in sterile polyethylene bags. All bags were incubated in pressure vessels under $450 \mathrm{~atm}$ at $2{ }^{\circ} \mathrm{C}$ for different periods up to $15 \mathrm{~d}$. At each time interval 1 pressure vessel was opened and the samples were immediately assayed for enzymatic activities. At several time intervals additional samples were taken for measurements of total phospholipids and microscopic direct counts.

Assay for enzymatic activity. Subsamples $(6 \mathrm{ml})$ were taken for each of the specific fluorogenic substrates (Table 1) from each bag. The substrates were dissolved in methylcellusolve by short ultrasonication $(10 \mathrm{~s}, 40 \mathrm{~W})$ and added to the subsamples at the saturation concentrations given in Table 1 to measure the maximal enzyme activity, in a modification of the method of Hoppe (1983). The enzyme assays were run in time course experiments ( 5 time intervals over 3 to 
Table 1 Investigated enzymes and their substrates. Names and enzyme classification numbers correspond to the IUB/IUPAC enzyme nomenclature. The natural substrates listed are only examples of the many compounds that are hydrolysed by these enzymes. The final concentrations of the artificial substrates were chosen after determination of the saturation levels, to avoid falsification of the measurements due to the different solubilities of the methylumbelliferone (MUF) and 4-methylcoumarinyl-7amide (MCA) substrates

\begin{tabular}{|lccc|}
\hline \multicolumn{1}{|c}{ Enzyme } & Typical natural substrate & Artificial substrate for assay & Final concentration (mM) \\
\hline $\begin{array}{l}\alpha \text {-Glucosidase } \\
\text { (E.C. } 3.2 .1 .20)\end{array}$ & Maltose (starch) & MUF- $\alpha$-glucoside & 50 \\
$\begin{array}{l}\beta \text {-Glucosidase } \\
\text { (E.C. } 3.2 .1 .21 \text { ) }\end{array}$ & Cellobiose (cellulose) & MUF- $\beta$-glucoside & 100 \\
$\begin{array}{l}\text { N-Acetyl- } \beta \text {-glucosaminidase } \\
\text { (chitobiase) (E.C. 3.2.1.30) }\end{array}$ & Chitobiose (chitin) & MUF-N-acetyl- $\beta$-glucosaminide & 100 \\
$\begin{array}{l}\text { Lipase } \\
\text { (E.C. } 3.1 .1 .23)\end{array}$ & Acylester (lipids, wax) & MUF-stearate & 50 \\
$\begin{array}{l}\text { Aminopeptidase } \\
\text { (E.C. 3.4.11.1) }\end{array}$ & Peptides (protein) & MCA-leucine & 500 \\
\hline
\end{tabular}

$5 \mathrm{~h})$ at $2^{\circ} \mathrm{C}$ and $1 \mathrm{~atm}$. Since the enzymes are highly barotolerant (Helmke \& Weyland 1986, Meyer-Reil \& Köster 1992) their activity at 1 atm and at in situ pressure was found to be similar (Lochte 1993). For each measurement, a $1 \mathrm{ml}$ subsample was removed, diluted with $2 \mathrm{ml}$ sterile filtered seawater to slow down the enzymatic reaction and $250 \mu \mathrm{l}$ of borate buffer $(\mathrm{pH} 10)$ was added to shift the $\mathrm{pH}$ to the range required for optimal fluorescence. The subsamples were centrifuged at 0 to $2{ }^{\circ} \mathrm{C}$ in a refrigerated centrifuge $(4000 \mathrm{rpm}$, $2800 \times g, 10 \mathrm{~min})$ and the release of methylumbelliferone (MUF) or 4-methylcoumarinyl-7-amide (MCA) was measured with a spectrofluorometer (PerkinElmer LS5B) at $365 \mathrm{~nm}$ excitation and $455 \mathrm{~nm}$ emission. MCA and MUF have slightly different fluorescence spectra, which introduces a small error when comparing the absolute values of the hydrolysis rates of MUF substrates and MCA-leucine. Since only relative comparisons of changes in enzyme activity were to be determined, for simplicity both substrates were measured at the same wavelengths and relative units of fluorescence of all substrates were calibrated with MUF standards in concentrations between 10 and $300 \mathrm{nM}$. Enzyme activity was calculated per volume of sediment and time $\left(\mathrm{mM} \mathrm{h}^{-1}\right)$ by linear regression of the enzyme activity against time. The regression coefficient was always better than 0.95 .

Total phospholipids. Subsamples for phospholipid measurements were taken immediately after the opening of each bag and stored frozen at $-20^{\circ} \mathrm{C}$ for later analysis at the home laboratory. Phospholipids were determined in 3 replicates from each subsample in a modification of the method of Findlay et al. (1989). Sediment slurries, chloroform and methanol (1:1:2) were mixed to a single phase in teflon centrifugation vials with screw-caps (Oak Ridge, Nalgene, New York, NY, USA) and allowed to extract for at least $12 \mathrm{~h}$. The phases were separated by adding the same volume of chloroform as before and an equal amount of distilled water After another $12 \mathrm{~h}$, the samples were centrifuged (6000 rpm, $4000 \times g, 10 \mathrm{~min}$ ). The aqueous phase on top was aspirated and the chloroform containing the phospholipids was filtered (Whatman V2) into a vial. Two ml of this chloroform extract was pipetted into $2 \mathrm{ml}$ glass ampoules (Wheaton) and the chloroform was completely removed from each ampoule under a stream of nitrogen in a waterbath at $40^{\circ} \mathrm{C}$. To liberate the lipidbound phosphate, $0.5 \mathrm{ml}$ of potassium persulfate $(5 \mathrm{~g}$ added to $100 \mathrm{ml}$ of $0.36 \mathrm{~N} \mathrm{H}_{2} \mathrm{SO}_{4}$ ) was added and the ampoules were heat sealed and incubated at $95^{\circ} \mathrm{C}$ overnight. The phosphate was determined according to the method of Findlay et al. (1989). Efficiency of phosphate liberation was determined as $89 \%$, recovery of phospholipid standards was as high as $87 \%$.

Microscopic direct counts. Sediment subsamples $(1 \mathrm{ml})$ were stored refrigerated in $2 \%$ formaldehyde. Bacterial numbers were determined by epifluorescence microscopy after staining with acridine orange according to the method of Meyer-Reil (1983).

\section{RESULTS}

\section{Cell growth due to substrate input}

Changes in biomass in the different incubations during the experiment determined via phospholipids are shown in Fig. 1a, b. The high phospholipid concentrations in samples enriched with POM at Day 0 are caused by the phospholipid content of the food material. Only a slight increase in biomass during the $15 \mathrm{~d}$ experiment was found in all incubations. The microorganisms supplied with $40 \mathrm{mMC}$ of DOM seemed to have doubled as early as Day 4 . However, due to high variability be- 


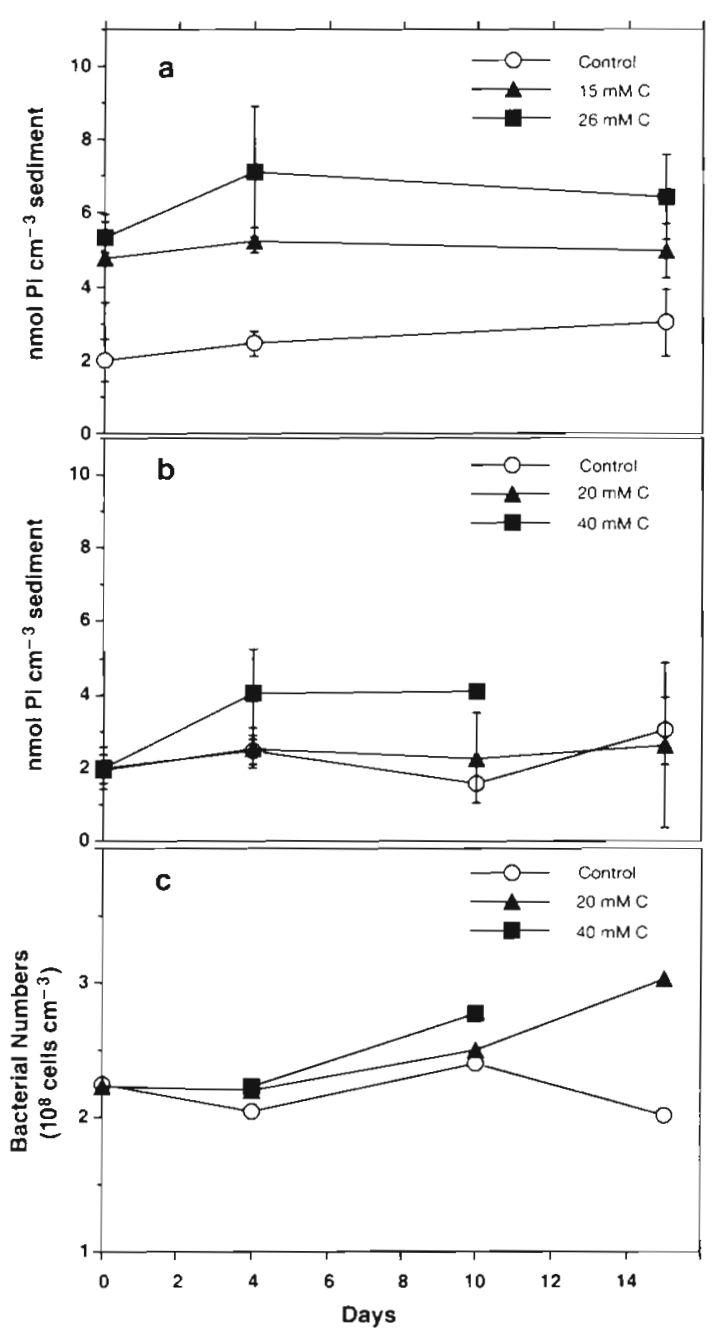

Fig. 1. (a, b) Changes in sediment phospholipid content, given in nmol liberated phosphate per $\mathrm{cm}^{3}$ sediment during $15 \mathrm{~d}$ of incubation after (a) addition of POM to final concentrations of 15 and $26 \mathrm{mM} \mathrm{C}$ and (b) addition of DOM to final concentrations of 20 and $40 \mathrm{mM} \mathrm{C}$. Unsupplemented samples served as control. Error bars: $95 \%$ level of confidence, $\mathrm{n}=3$. (c) Changes in bacterial numbers during $15 \mathrm{~d}$ of incubation after addition of DOM to final concentrations of 20 and $40 \mathrm{mM} \mathrm{C}$. At each sampling time 2 samples were analyzed, indicated by the symbols; the line represents the average

tween the replicates the differences in phospholipid content between incubation times were not significant at the $95 \%$ level of confidence. Unfortunately, restrictions in sample material did not allow further measurements at more time intervals.

Bacterial numbers determined by microscopic direct counts gave results similar to those from the phospholipid determinations (Fig. 1c). During the $15 \mathrm{~d}$ experiment, bacterial numbers changed from $2.2 \times 10^{8}$ cells $\mathrm{ml}^{-1}$ sediment slurry to $2.0 \times 10^{8}$ cells $\mathrm{ml}^{-1}$ in samples without additions and to $3.0 \times 10^{8}$ cells ml $\mathrm{ml}^{-1}$ in samples

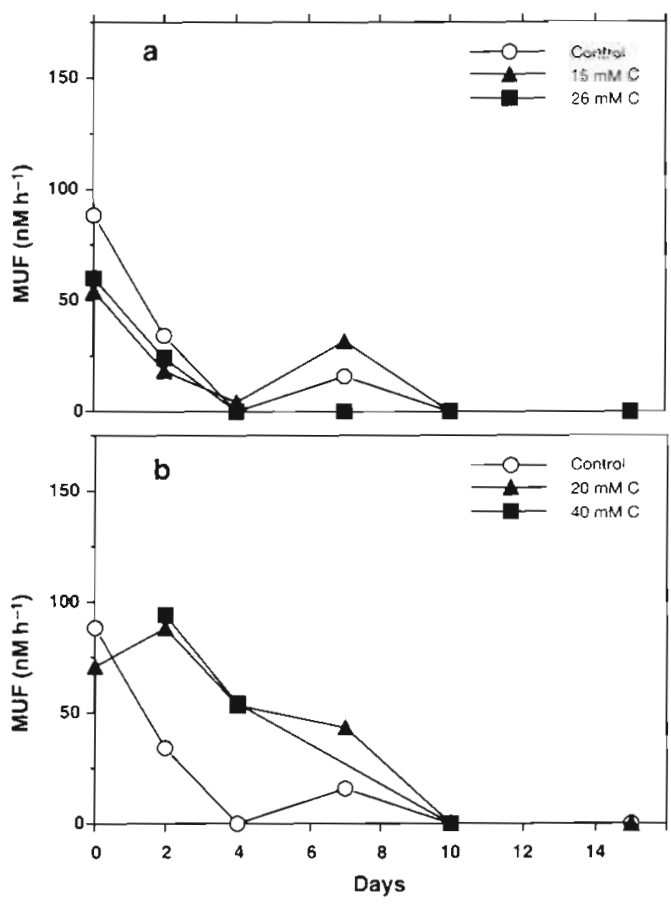

Fig. 2. Changes in potential hydrolytic activity of lipase during $15 \mathrm{~d}$ of incubation after (a) addition of POM to final concentrations of 15 and $26 \mathrm{mM} \mathrm{C}$ and (b) addition of DOM to final concentrations of 20 and $40 \mathrm{mM} \mathrm{C}$. Unsupplemented samples served as a control. Each data point represents a 5 -point time course incubation assayed by linear regression; $r \geq 0.95$

having received $20 \mathrm{mM} \mathrm{C}$ of DOM. The differences between treatments were not statistically significant at the $95 \%$ level of confidence. However, the slight increase in bacterial numbers towards the end of the experiment in samples supplied with DOM may indicate the onset of bacterial growth. Samples amended with POM could not be counted microscopically due to interference from detrital matter.

\section{Enzyme regulation due to substrate input}

The enzymatic activity determined at saturation level of the fluorogenic substrate is directly related to the amount of enzyme present in the sample. Changes in activity during the experiment are, therefore, caused by the production or decay of hydrolytic enzymes. The reactions of the investigated enzymes to food supply can be separated into 3 groups:

(1) Lipase and $\alpha$-glucosidase activity showed no clear response to substrate addition. Lipase activity ceased after $7 \mathrm{~d}$ (Fig. 2a, b); $\alpha$-glucosidase stayed at a very low level throughout the experiment (Fig. 3a, b). Between Day 10 and Day 15 an increase in enzyme 


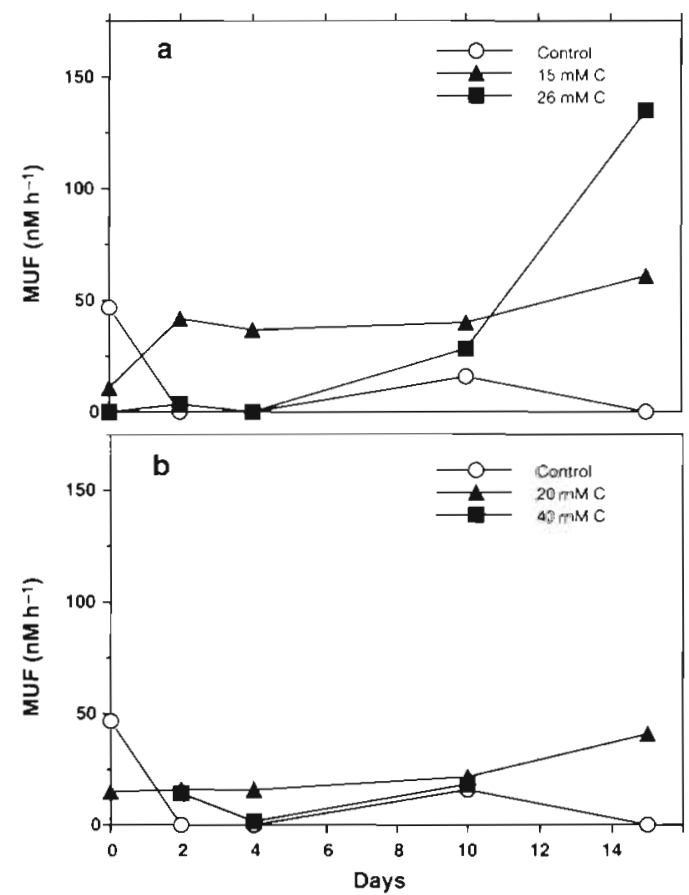

Fig. 3. Changes in potential hydrolytic activity of $\alpha$-glucosidase (for explanations see Fig. 2)

activity occurred in the incubations with POM added at a concentration of $26 \mathrm{mM}$ organic C (Fig. 3b).

$\beta$-Glucosidase and chitobiase activity was induced by substrate addition, responding proportionally to the amount of POM input. During the course of the experiment an overall increase in $\beta$-glucosidase activity with time was measured in the enriched incubations. The activity level was much higher when particulate material was added (Fig. 4a) than dissolved material (Fig. 4b). The increase due to addition of particulate material was detectable after $7 \mathrm{~d}$. While the low POM addition caused enzyme activity to rise until Day 10 , after which it remained constant, with the high POM addition enzyme activity continued to increase until Day 15. With DOM supply a substantial increase in enzyme activity was evident after $4 \mathrm{~d}$, being approximately twice as high in the samples doubly enriched. Enzyme activity decreased slightly towards the end of the experiment.

The induction of chitobiase activity took a course similar to that described above, although the reaction to DOM addition was stronger than with $\beta$-glucosidase (Fig. 5a). Enzyme activity increased throughout the experiment in incubations with high additions of dissolved and particulate material (Fig. 5b), while with the low additions enzyme activity did not increase any further after Day 10.

(3) Aminopeptidase activity showed a totally different reaction to substrate input. Throughout the experi-
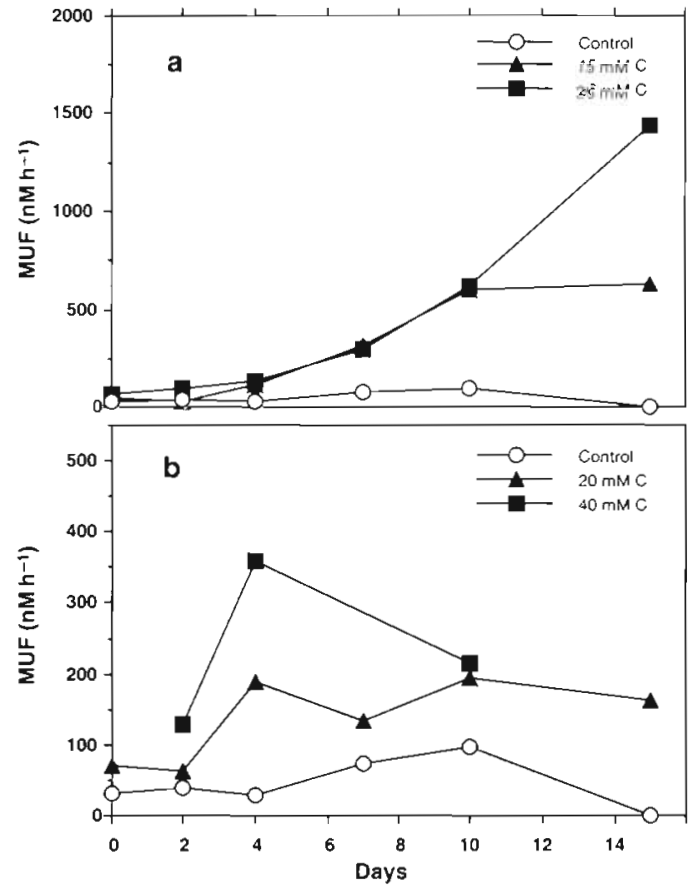

Fig. 4. Changes in potential hydrolytic activity of $\beta$-glucosidase (for explanations see Fig. 2). Note differences in scale

ment, enzymatic activity in the DOM-enriched samples was about half that in the control (Fig. 6a). No difference could be detected between the addition of single and double amounts of DOM. Until Day 10, in samples supplied with POM (Fig. 6b), aminopeptidase activity was slightly lower in the enriched than in the control incubations. Towards the end of the experiment, enzyme activity increased in the enriched samples exceeding the activity in the control incubation by a small amount.

\section{Quantitative response to food input}

The enzyme activity determined at Day 0 was assumed to correspond to that of the natural environment. After $15 \mathrm{~d}$ of incubation under in situ conditions the enhancement of enzyme activity relative to the activity at Day 0 was estimated (Fig. 7). The enhancement effect caused by addition of DOM could only be estimated for the lower concentration of $20 \mathrm{mM}$ organic $\mathrm{C}$ since the samples with higher DOM concentrations were incubated only up to $10 \mathrm{~d}$.

Increases in enzymatic activity proportional to the amount of POM added were found for $\beta$-glucosidase and chitobiase. Approximately double amounts of POM (26 mM organic C) elicited enhancement of activity twice as high as in samples receiving single POM additions ( $15 \mathrm{mM}$ organic $\mathrm{C}$ ). Even the activity of 

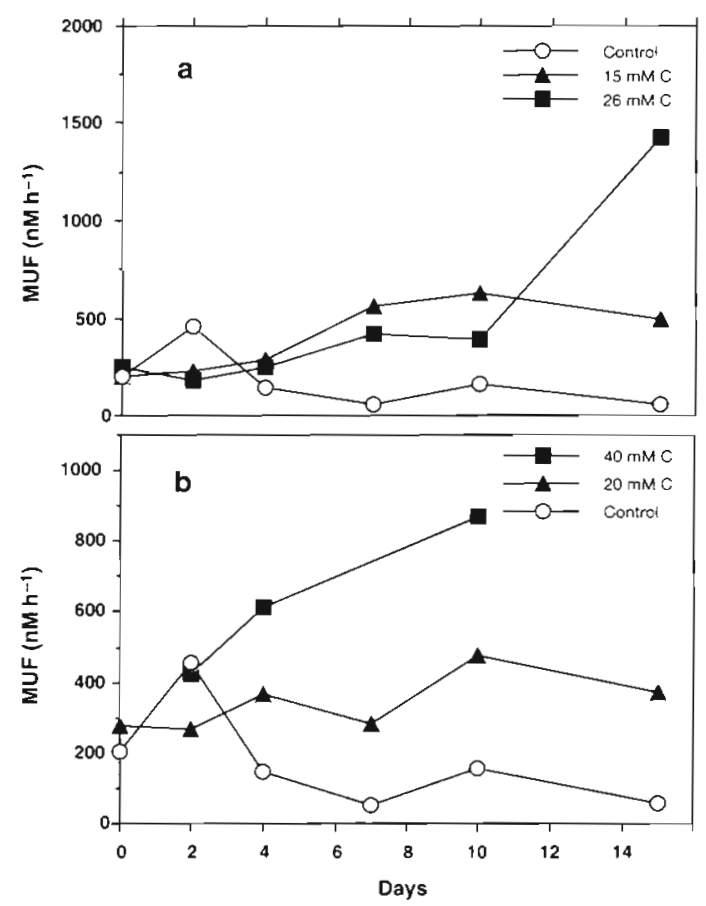

Fig. 5. Changes in potential hydrolytic activity of chitobiase (for explanations see Fig. 2). Note differences in scale

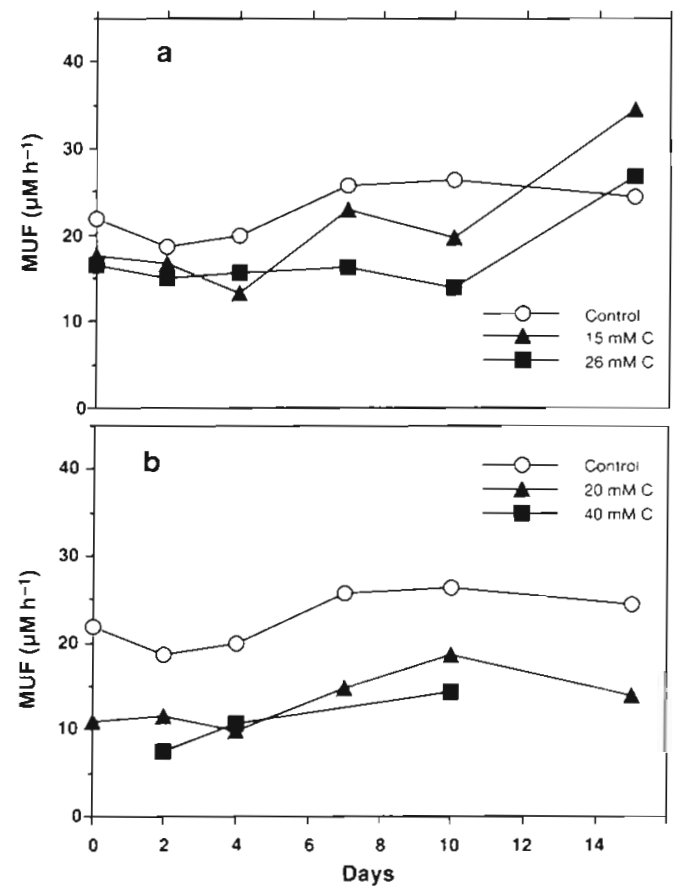

Fig. 6. Changes in potential hydrolytic activity of aminopeptidase (for explanations see Fig. 2)

$\alpha$-glucosidase followed this pattern, although this enzyme showed little response to substrate addition during the initial period of incubation (Fig. 3a).

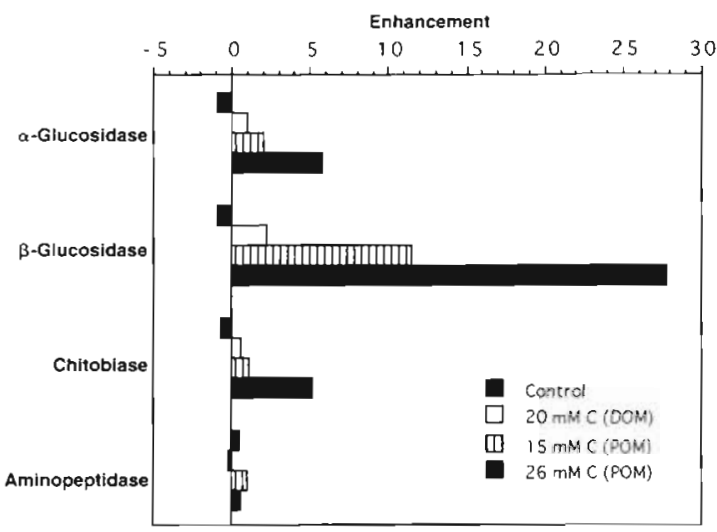

Fig. 7. Enhancement of potential hydrolytic activity in deepsea sediments after addition of particulate (POM) and dissolved (DOM) organic material. The enhancement of enzymatic activities $(E)$ is calculated as $E=A_{15} / A_{0}-1$, where $A_{0}=$ the 'natural' level of activity at Day $0 ; A_{15}=$ enzyme activ ity at Day 15. Negative values show a decrease in activity compared to the natural level. An enhancement of enzyme activity until Day 15 in the control (unsupplemented samples) was only found in the case of aminopeptidase. Lipase activity

is not shown as it ceased after $7 \mathrm{~d}$

Aminopeptidase activity decreased with DOM addition and increased only slightly at Day 15 when POM was added. Lipase activity had ceased after $7 \mathrm{~d}$ and no effect of food supply was detectable (not shown).

\section{DISCUSSION}

The changes in hydrolytic enzyme activities observed during the incubation were much larger than biomass changes and, therefore, have to be related to inducible enzyme production rather than to biomassdependent, constitutive production of enzymes. This latter mechanism would have produced a constant enzymatic activity per cell.

Microbial degradation of particles requires their colonization by bacteria, since a substantial fraction of the extracellular enzymes are bound to the cell membranes or other surfaces (Hoppe 1983, Rego et al. 1985, Meyer-Reil 1990, Martinez \& Azam 1993). Thus oniy a relatively small surface area can be attacked by the hydrolytic enzymes and enzyme production may be induced only in microorganisms in the vicinity of the particle (Karner \& Herndl 1992). The more particles and particle surfaces available, the higher the chance of contact with bacterial cells and subsequent enzyme induction. We hypothesize that a steadily present low level of extracellular enzymes triggers the mechanisms of substrate induction by hydrolyzing a small amount of new inputs of macromolecular organic matter, since only the subunits can enter the cells and cause the reg- 
Table 2. Enhancement of enzyme activities over $15 \mathrm{~d}$ (according to Fig. 7) normalized to the concentration of added organic carbon. Lipase activity is not shown as it ceased after $7 \mathrm{~d}$

\begin{tabular}{|c|c|c|c|}
\hline \multirow[t]{2}{*}{ Enzyme } & \multicolumn{2}{|c|}{ Incubation with POM } & \multirow{2}{*}{$\begin{array}{l}\text { Incubation with DOM } \\
\qquad 20 \mathrm{mMC}\end{array}$} \\
\hline & $26 \mathrm{mMC}$ & $15 \mathrm{mMC}$ & \\
\hline$\alpha$-Glucosidase & 221 & 133 & 53 \\
\hline$\beta$-Glucosidase & 1069 & 767 & 112 \\
\hline $\begin{array}{l}N \text {-Acetyl- } \beta \text { - } \\
\text { glucosaminidase } \\
\text { (chitobiase) }\end{array}$ & 201 & 78 & 31 \\
\hline Aminopeptidase & 23 & 71 & -8.5 \\
\hline
\end{tabular}

In the incubations, the addition of homogenized and autoclaved POM and DOM from net plankton led to a substantial induction of $\beta$-glucosidase as well as chitobiase depending on the amount of supplied substrate. Both hydrolases are part of the enzymatic systems that hydrolyse cellulose and chitin respectively. These are the most common structural saccharide compounds to be found in a mixture of plant and animal tissues. Since they are less degradable than for example starch, which contains

ulatory mechanisms to react. Dissolved macromolecular matter diffusing through the sediment has a much greater chance of coming into contact with bacteria and their membrane-bound enzymes and, hence, could potentially induce enzyme production more effectively. However, the opposite effect was observed in our experiments.

A striking difference in microbial reaction to particulate and dissolved substrates becomes obvious when the enzyme induction by POM and DOM is normalized to the amount of carbon supplied (Table 2). The relative effect of a unit of organic carbon was much higher in the particulate than in the dissolved phase. This effect could have been caused by the high content of mono- or oligomeric organic matter in the DOM supply that was directly utilizable by the microorganisms without production of additional hydrolytic enzymes. Catabolic repression of enzyme production could have been the cause of the lower enzyme production in the case of DOM utilization compared to POM.

Investigations of various extracellular enzymes from natural sediment populations from the deep sea and the Antarctic as well as from psychrophilic bacterial strains demonstrated that temperature optima for enzyme activities ranged between 20 and $40^{\circ} \mathrm{C}$ (Reichardt 1987, 1988, Helmke \& Weyland 1991, Meyer-Reil \& Köster 1992) and that they were active over a wide range of pressures (Helmke \& Weyland 1986, Meyer-Reil \& Köster 1992). In contrast, the processes of production of bacterial enzymes may well be adapted to deep-sea conditions. For the protein synthesis mechanisms that also regulate enzyme production, optima of temperature and pressure were found to be within the range typical for the respective environments (Somero et al. 1983, Reichardt 1988). Under simulated in situ conditions the reactivity of the native deep-sea microbial population was on a time scale comparable to those of other environments such as lake water (Chróst 1991) or subtidal sediments (MeyerReil 1987). $\alpha$-glucosidic bonds, they may well reach the deepsea bottom as sinking particulate matter.

Lipase activity was not induced but declined and finally stopped in all incubations during the experiment (Fig. 2). The $\alpha$-glucosidase only increased $10 \mathrm{~d}$ after the addition of POM (Fig. 3a). This lack of response is possibly caused by the pretreatment of our plankton homogenate which was sterilized by autoclaving. This may lead to partial hydrolysation by heat of lipids and starch. Furthermore, starch and lipids are comparatively labile storage compounds and are likely to be rapidly consumed during sedimentation in the water column. Their importance as nutritional compounds for deep-sea microorganisms and, hence, the amount of the respective hydrolytic enzymes produced by the natural populations may be small. In addition to these ecological considerations, the suitability of the employed fluorogenic model substrate for general lipolytic enzyme activity has to be scrutinized in further tests.

Aminopeptidase activity was significantly lowered by the addition of DOM throughout the experiment as well as by POM during the first $10 \mathrm{~d}$. We are not sure which of the many regulatory mechanisms were causing the immediate decrease in aminopeptidase activity and also its continuing repression. Since this effect was apparent directly after the addition of the homogenized net plankton, particularly with the dissolved phase, we assume that competitive inhibition due to a high content of amino acids or oligomeric peptides within the added food reduced the activity of the enzyme with respect to the artificial fluorogenic substrate. Competitive inhibition due to addition of nonfluorogenic substrate while measuring different enzymes with the respective MUF substrates was shown by Hoppe (1983) and Somville \& Billen (1983).

The long-term suppression of aminopeptidase could also be caused by other mechanisms of enzyme regulation. For example, a decrease in peptidase activity due to catabolite repression can result from addition of amino acids as found in investigations with isolated 
bacterial strains (Coleman et al. 1987) as well as with lake-water samples (Chróst 1991). This effect is caused by the reduction in the affinity of mRNA for a promoter, causing a decrease in enzyme formation. In addition, the activity of an enzyme can be regulated by the effect of competition (Coleman et al. 1987) when catabolites stimulating growth are present in high amounts shifting the cell metabolism towards growth. This inhibits enzyme production by changing the concentrations of the cellular components involved in the regulation of transcription.

Further indications for the regulation of aminopeptidase activity were observed in laboratory experiments as well as in field studies when natural substrates with high contents of saccharides, as in plant material, were present (unpubl. results). An inverse relationship was found between the activity of aminopeptidase and the activities of $\alpha$ - and $\beta$-glucosidase and chitobiase. The latter enzymes showed high activity when substrate availability was high while aminopeptidase activity was reduced. This cannot be explained by the mechanisms of competitive inhibition only, so that other regulatory mechanisms for aminopeptidase are to be expected and require further investigation.

Total biomass increased only slightly during the course of the incubations. We suspect that the duration of the experiment was too short to record significant growth of bacterial cells as a response to the input of organic material. It is obvious, however, that activation of hydrolytic enzymes precedes any bacterial growth. In experiments carried out at the same station in July 1986 with detrital matter sterilized by gamma irradiation, growth of deep-sea bacteria was observed under in situ conditions (Turley \& Lochte 1990). The concentration of added organic matter, which contained both dissolved and particulate material, was 10 -fold lower (1.7 mM organic carbon) than in the present enrichment experiments. While bacterial numbers increased significantly only after $20 \mathrm{~d}$, the increase in bacterial biomass was mainly dependent on the enlargement of cells. In natural deep-sea phytodetritus incubated under in situ conditions, rapid multiplication of bacterial cells was found in the first $2 \mathrm{~d}$ (Lochte \& Turley 1988). Supplying sediment cores from the Vøring Plateau (Norwegian Sea, $1240 \mathrm{~m}$ ) with sterilized planktonic and detrital matter $\left(9.2 \mathrm{mmol} \mathrm{C} \mathrm{cm}^{-2}\right)$ produced no measurable increase in either microbial numbers or biomass within $10 \mathrm{~d}$ (Köster et al. 1991). These discrepancies in growth response of microbial sediment populations after the addition of natural substrate indicate that biomass production is not directly related to quantity of food input. A measurable growth response can only result when the exploitable energy content of the food is sufficiently high, therefore growth efficiencies vary greatly depending on the type of organic matter utilized. A gradual decrease in growth efficiency with proceeding degradation of detrital matter was observed for deep-sea bacteria (Turley \& Lochte 1990).

In this investigation we found both substrate induction and inhibition to be mechanisms regulating the potential activity of different specific hydrolytic enzymes of a natural microbial community from deepsea sediments. The differences in the response of the investigated hydrolytic enzymes to the addition of organic matter indicate that the amounts of enzymes present in sediments are coupled to the availability and the quality of their specific substrates and are not directly dependent on the biomass of their producers. The organic matter employed for this experimental approach is not representative of naturally occurring deep-sea detritus. For instance, the amount of low molecular peptides causing competitive inhibition of aminopeptidase would presumably be lower in aged detrital matter. However, with some modifications, similar regulation mechanisms of hydrolytic enzyme activity and production are likely to occur in deep-sea sediments. Further investigations of the regulation of hydrolytic enzymes by substrates and catabolites are necessary to understand fully the relationships between macromolecular organic material and enzymatic activities. Once these relationships are known, measurement of enzymatic activities may give information on the types of organic materials biologically utilized in different deep-sea areas.

Acknowledgements. We thank scientists and crew on cruise METEOR 21/6 tor making multiple corer samples available. Many thanks are due to Annelie Skoog for the DOC measurements and Victor Smetacek and Hans-Georg Hoppe for helpful comments on the manuscript. This is BIOTRANS publication no. 30 and publication no. 669 of the Alfred Wegener Institute for Polar and Marine Research

\section{LITERATURE CITED}

Alldredge, A. L., Silver, M. W. (1988). Characteristics, dynamics and significance of marine snow. Prog. Oceanogr. 20: $41-82$

Banse, K. (1990). New views on the degradation and disposition of organic particles as collected by sediment traps in the open sea. Deep Sea Res. 37: 1177-1195

Barnett, P. R. O., Watson, J., Connelly, D. (1984). A multiple corer for taking virtually undisturbed samples from shelf, bathyal and abyssal sediments. Oceanol. Acta 7: 399-408

Billen, G. (1982). Modelling the processes of organic matter degradation and nutrients recycling in sedimentary systems. In: Nedwell, D. B., Brown, C. M. (eds.) Sediment microbiology. Academic Press, London, p. 15-52

Boetius, A. (in press). Microbial hydrolytic enzyme activities in deep-sea sediments. Helgoländer Meeresunters. 49

Chróst, R. J. (1991). Environmental control of the synthesis and activity of aquatic microbial ectoenzymes. In: Chróst, R. J. (ed.) Microbial enzymes in aquatic environments. 
Springer-Verlag, Berlin, p. 29-59

Chróst, R. J., Overbeck, J. (1990). Substrate-ectoenzyme interaction: significance of $\beta$-glucosidase activity for glucose metabolism by aquatic bacteria. Arch. Hydrobiol. Beih. Ergebn. Limnol. 34: 93-98

Coleman, G., Abbas-Ali, B., Sutherland, J., Fyfe, L., Finlay, A. (1987). A comparison of the characteristics of extracellular protein secretion by a Gram-positive and a Gram-negative bacterium. In: Chaloupka, J., Krumphanzl, V. (eds.) Extracellular enzymes of microorganisms. Plenum Press, New York, p. 13-21

Findlay, R. H., King, G. M., Watling, L. (1989). Efficacy of phospholipid analysis in determining microbial biomass in sediments. Appl. environ. Microbiol. 55: 2888-2893

Grasshoff, K., Erhardt, M., Kremling, K. (1983). Methods of seawater analysis. Verlag Chemie, Weinheim

Helmke, E., Weyland, H. (1986). Effect of hydrostatic pressure and temperature on the activity and synthesis of chitinases of Antarctic Ocean bacteria. Mar. Biol. 91: 1-7

Helmke, E., Weyland, H. (1991). Effect of temperature on extracellular enzymes occurring in permanently cold marine environments. Kieler Meeresforsch., Sonderh. 8: 198-204

Hoppe, H.-G. (1983). Significance of exoenzymatic activities in the ecology of brackish water: measurements by means of methylumbelliferyl-substrates. Mar. Ecol. Prog. Ser. 11 299-309

Hoppe, H.-G. (1991). Microbial extracellular enzyme activity: a new key parameter in aquatic ecology. In: Chróst, R. J (ed.) Microbial enzymes in aquatic environments. Springer-Verlag, Berlin, p. 60-80

Hoppe, H.-G., Ducklow, H., Karrasch, B. (1993). Evidence for dependency of bacterial growth on enzymatic hydrolysis of particulate organic matter in the mesopelagic ocean. Mar. Ecol. Prog. Ser. 93: 277-283

Karl, D. M., Knauer, G. A., Martin, J. H. (1988). Downward flux of particulate organic matter in the ocean: a particle decomposition paradox. Nature 332: 438-441

Karner, M., Hernd!, G. J. (1992). Extracellular enzymatic activity and secondary production in free-living and marine-snow-associated bacteria. Mar. Biol. 113: 341-347

Köster, M., Charfreitag, O., Meyer-Reil, L.-A. (1991). Availability of nutrients to a deep-sea benthic microbial community: results from a ship-board experiment. Kieler Meeresforsch., Sonderh. 8: 127-133

Lee, J. J. (1980). A conceptual model of manne detrital decomposition and the organisms associated with the process. Adv. aquat. Microbiol. 2: 257-291

Lochte, K. (1991). Bacterial standing stock and consumption of organic carbon in the benthic boundary layer of the abyssal North Atlantic. In: Rowe, G. T., Pariente, V. (eds.) Deep sea food chains and the global carbon cycle. Kluwer Academic Press, Dordrecht, p. 1-10

Lochte, K. (1993). Mikrobiologie von Tiefseesedimenten. In: Meyer-Reil, L.-A., Köster, M. (eds.) Mikrobiologie des Meeresbodens. Fischer Verlag, Jena, p. 258-282

Lochte, K., Turley, C. M. (1988). Bacteria and cyanobacteria associated with phytodetritus in the deep sea. Nature 333 $67-69$

Martinez, J., Azam, F. (1993). Periplasmic aminopeptidase and alkaline phosphatase activities in a marine bacterium: implications for substrate processing in the sea. Mar. Ecol. Prog. Ser. 92: 89-97
Meyer-Reil, L.-A. (1983). Benthic response to sedimentation events during autumn to spring at a shallow water station in the western Kiel Bight. Mar. Biol. 77: 247-256

Meyer-Reil, L.-A. (1987). Seasonal and spatial distribution of extracellular enzymatic activities and microbial incorporation of dissolved organic substrates in marine sediments. Appl. environ. Microbiol. 53: 1748-1755

Meyer-Reil, L-A. (1990). Microorganisms in manne sediments: considerations concerning activity measurements Arch. Hydrobiol. Beih. Ergeb. Limnol. 34: 1-6

Meyer-Reil, L-A. (1991). Ecological aspects of enzymatic activity in marine sediments. In: Chróst, R. J. (ed.) Microbial enzymes in aquatic environments. Springer-Verlag, Berlin, p. 84-95

Meyer-Reil, L.-A., Köster, M. (1992). Microbial life in pelagic sediments: the impact of environmental parameters on enzymatic degradation of organic material. Mar. Ecol. Prog. Ser. 81. 65-72

Pfannkuche, O. (1993). Benthic response to the sedimentation of particulate organic matter at the BIOTRANS station, $47^{\circ} \mathrm{N}, 20^{\circ} \mathrm{W}$. Deep Sea Res. 40: 135-149

Pfannkuche, O., Beckmann, W., Christiansen, B., Lochte, K. Reinheimer, G., Thiel, H., Weikert, H. (1990). Biologischer Vertikaltransport und Energiehaushalt in der bodennahen Wasserschicht der Tiefsee. Berichte aus dem ZMK der Universität Hamburg 10: 16-51

Priest, F. G. (1984). Extracellular enzymes. Van Nostrand Reinhold Co. Ltd, Wokingham, p. 79

Rego, J. V., Billen, G., Fontigny, A., Somville, M. (1985). Free and attached proteolytic activity in water environments. Mar. Ecol. Prog. Ser. 21: 245-249

Reichardt, W. (1987). Differential temperature effects on the efficiency of carbon pathways in Antarctic marine benthos. Mar. Ecol. Prog. Ser. 40: 127-135

Reichardt, W. (1988). Impact of the antarctic benthic fauna on the enrichment of biopolymer degrading psychrophilic bacteria. Microb. Ecol. 15: 311-321

Rowe, G., Sibuet, M., Deming, J., Khripounotf, A., Tietjen, J., Macko, S., Theroux, R. (1991). 'Total' sediment biomass and preliminary estimates of organic carbon residence time in deep-sea benthos. Mar. Ecol. Prog. Ser. 79: 99-114

Rutgers van der Loeff, M. M. (1990). Oxygen in pore waters of deep-sea sediments. Phil. Trans. R. Soc. Lond. A 331. $69-84$

Smith, D. C., Simon, M., Alldredge, A. L., Azam, F. (1992) Intense hydrolytic enzyme activity on marine aggregates and implications for rapid particle dissolution. Nature 359: $139-142$

Somero, G., Siebenaller, J. F., Hochachka, P. W. (1983). Biochemical and physiological adaptation of deep-sea animals. In: Rowe, G. T (ed.) The sea, Vol. 8, Deep-sea biology. John Wiley \& Sons, New York, p. 261-329

Somville, M., Billen, G. (1983). A method for determining exoproteolytic activity in natural waters. Limnol. Oceanogr. 28: $190-193$

Tietjen, J. H. (1992). Abundance and biomass of metazoan meiobenthos in the deep sea. In: Rowe, G. T., Pariente, V. (eds.) Deep-sea food chains and the global carbon cycle. Proc. NATO ARW, Kluwer Academic Publishers, Dordrecht, p. 45-62

Turley, C. M., Lochte, K. (1990). Microbial response to the input of fresh detritus to the deep-sea bed. Palaeogeogr Palaeoclimatogr. Palaeoecol. 89: 3-23

Manuscript first received: August 11, 1993

Revised version accepted: November 10, 1993 